\title{
Uvajanje e-poslovanja na sodišče kot storitev e-uprave
}

\author{
UDK: 430:659.2:004 \\ Benjamin Lesjak \\ Univerza v Mariboru, Pravna fakulteta \\ benjamin.lesjak@uni-mb.si
}

\begin{abstract}
IZVLEČEK
V prispevku avtor pojasni pojav e-poslovanja na sodišču in možnosti informatizacije sodnega postopka. Ob tem opozori na slovensko zakonodajo v zvezi z e-poslovanjem v civilnem postopku na sodišču in na spremenjeno zakonodajo $v$ upravnem postopku, $k i$ uvaja bistvene novosti za e-poslovanje. Kratko opiše dejavnosti v okviru Akcijskega načrta e-uprave do leta 2004, kjer je bilo pravosodje zajeto kot eno izmed področij, in omeni e-storitve na področju informacijskih sistemov za spremljanje sodnih postopkov ter druge pravne storitve. Predstavi nekatere oblike uporabe informacijske tehnologije na sodišču ter raziskavo o možnostih uvedbe e-poslovanja na sodišča, ki jo je izvedel med slovenskimi pravniki konec leta 2003. Predstavljena je prototipna rešitev, ki omogoča strankam $v$ sodnem procesu, da elektronsko vlagajo dokumente na sodišče. Z nekaterimi sodelujočimi slovenskimi pravniki opravi preizkus prototipne rešitve, tako da izvedejo simulacijo sodnega postopka na podlagi namišljenega primera $v$ elektronski obliki.
\end{abstract}

Ključne besede: e-poslovanje, e-uprava, sodišča, pravosodje, sodni postopek.

\section{Uvod}

Ko opredeljujemo e-poslovanje, mislimo predvsem na uporabo svetovnega spleta in drugih storitev $\vee$ komercialne oziroma gospodarske namene, zato navajamo nekaj avtorjev s tega področja. Toplišek (1998, str. 4) opredeljuje e-poslovanje kot: dejavnost, ki obsega: elektronsko izmenjavo podatkov kot način dela; širok obseg poslovanja: blago in storitve, plačevanje, pred- in poprodajne dejavnosti, delovanje javnih služb; potrošnike, podjetja in državo (javne službe) kot tri glavne skupine udeležencev. Gričar (1997, str. 245) navaja, da e-poslovanje poenostavljeno pomeni poslovati elektronsko, pri čemer to poslovanje v najširšem smislu vključuje uporabo vseh oblik informacijske tehnologije $\vee$ poslovnih odnosih med trgovinskimi, proizvodnimi in storitvenimi organizacijami, ponudniki podatkov, potrošniki in državno upravo. Clarke (2004) omenja e-poslovanje kot "e-business" in "e-commerce». »E-business « razume kot postopek poslovanja s pomočjo telekomunikacijskih in podobnih orodij na njihovi osnovi in ga ločuje od "e-commerce« kot postopka trgovanja z 


\section{Benjamin Lesjak \\ Uvajanje e-poslovanja na sodišče kot storitev e-uprave}

blagom in storitvami s pomočjo telekomunikacijskih in podobnih orodij na njihovi osnovi.

Kakor na vseh področjih je tudi v pravosodju opaziti potrebe po uvajanju e-poslovanja kot načina poslovanja znotraj same organizacije kakor tudi med strankami, ki s pravosodjem dnevno sodelujejo oziroma "poslujejo «". Pri raziskovanju e-poslovanja v pravosodju smo se osredotočili predvsem na poslovanje, sodelovanje, komunikacijo in interakcijo med strankami ter sodiščem pri izvedbi civilnega pravdnega postopka od vložitve tožbe do izrečene sodbe na prvostopenjskem sodišču. Če poskušamo na kratko opredeliti tovrstno poslovanje, lahko trdimo, da gre za poslovanje posameznikov oz. podjetij z državo kot obliko zagotavljanja posebnih storitev, posredovanja podatkov, kjer ne govorimo o trgovanju (e-commerce).

Tradicionalno je znano, da so pravosodna veja oblasti kakor tudi njeni akterji, sodniki, nekateri odvetniki in drugi sodelujoči pri razvoju in uvajanju sodobne informacijske tehnologije $v$ zaostanku, zato je zahteva po razvoju in uvajanju e-poslovanja $\checkmark$ pravosodje prišla z druge veje oblasti, to je izvršilne ali natančneje, $v$ okviru razvoja e-uprave (e-government).

$\checkmark$ primeru elektronskega poslovanja med strankami na sodišču (odnos: sodišče - stranka) je teže govoriti o G2C (government-to-citizen) ali G2B (government-to-business) poslovanju državnega/upravnega organa s stranko in obratno, kot bi lahko izhajalo iz dobesednega prevoda črke G, kajti pravosodna oblast je ob izvršilni in zakonodajni ena izmed vej oblasti, zato je treba pri elektronskem poslovanju na sodišču udeležence, ki jih označujemo s črko G (government) opredeliti širše kot samo "government" oziroma izvršilno oblast, vlado ali upravo. Bolj smiselna opredelitev bi bila javni sektor. Tako se tudi v Akcijskem načrtu e-uprave do leta 2004 (CVI 2004, str. 18-19, 26-27) pravosodje obravnava kot storitev pod G2C, G2B oziroma G2G. ${ }^{2}$ Besedno zvezo "e-government" in njen prevod e-uprava moramo razumeti kot program e-poslovanja $v$ javnem sektorju.

\section{Zakonska podlaga e-poslovanju v pravosodju}

Delno obliko vzpostavitve e-poslovanja na sodišču predstavlja storitev e-vložitev ali elektronske vloge, ki se v angleško govorečih državah pojavlja kot izraz "e-filing" (Toplišek 1998, str. 5). V vodiču o elektronski vložitvi na sodišču (McMillan 1998) navajajo, da je elektronska vložitev dokumenta na sodišče proces prenosa in izmenjave

1 S tem razlogom je avtor na to temo opravil raziskavo in v letu 2004 uspešno zagovarjal magistrsko delo z naslovom: "Uvajanje e-poslovanja med strankami na sodišču s prototipno rešitvijo«.

2 O obsegu e-uprave so pojasnjevali na nekdanjem Ministrstvu za informacijsko družbo (MID), kamor so pod e-upravo prištevali tudi sodstvo. 


\section{Benjamin Lesjak \\ Uvajanje e-poslovanja na sodišče kot storitev e-uprave}

vlog in drugih informacij s sodiščem prek elektronskega medija in ne prek papirja. Elektronska vložitev omogoča, da se večina dela opravi s pomočjo osebnega računalnika, to je pošiljanje in prejemanje dokumentov, plačevanje obveznosti iz tega naslova, obveščanje drugih strank, prejemanje obvestil sodišča in komuniciranje s sodiščem.

Slovenska procesna zakonodaja, ki določa postopke na sodiščih, v nekaterih predpisih in členih sicer omenja možnost elektronskega poslovanja. Teoretično je možno vlogo na sodišče vložiti tudi $v$ elektronski obliki, kot to določa 105. člen Zakona o pravdnem postopku (ZPP). Namreč za vlogo, prejeto z uporabo komunikacijske tehnologije, in za vlogo, prejeto $v$ skladu s pogoji, ki jih zakon določa za uporabo informacijske tehnologije, se šteje, da jo je podpisala oseba, ki je na vlogi

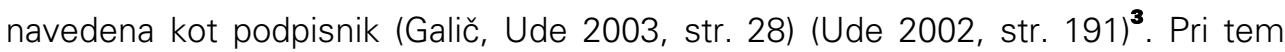
Zakon o pravdnem postopku ZPP upošteva Zakona o elektronskem poslovanju in elektronskem podpisu (ZEPEP), ki $\vee$ 4. členu določa, da se podatkom $\vee$ elektronski obliki ne sme odreči veljavnosti ali dokazne vrednosti samo zato, ker so $v$ elektronski obliki ${ }^{4}$.

Vloge, vključno s prilogami, ki jih treba vročiti nasprotni stranki, mora stranka poslati $\vee$ toliko izvodih, kolikor jih je potrebnih za sodišče in za nasprotno stranko ter $v$ taki obliki, da jih sodišče lahko vroči (določilo 106. člena ZPP). Ob navedenem se pojavi smiselno vprašanje elektronskega pošiljanja vlog. Namreč za elektronsko obliko velja, da ne ločuje med originali in med kopijami sporočila (vloge) in da je pri elektronski obliki vsaka kopija hkrati original. Torej je smiselno sklepati, da naj se vloge v elektronski obliki pošiljajo le enkrat.

Sodni spisi, to so vabila, sodne odločbe in vloge nasprotne stranke, se strankam vročajo $v$ pisni obliki po pošti ali po določenem delavcu sodišča. Problem se pojavi pri vročanju vloge $v$ elektronski obliki nasprotni stranki. Ali je dovoljeno vročanje pisanj $v$ elektronski obliki? Z upoštevanjem ZEPEP bi to lahko bilo teoretično možno, vendar tovrsten način $v$ praksi ni mogoč, vsaj ne $v$ sodnih postopkih.

Drugače je $v$ upravnih postopkih, kjer je z novelo Zakona o splošnem upravnem postopku (ZUP) ${ }^{\mathbf{5}}$ mogoče poslovati elektronsko $v$ večjem obsegu kot $v$ sodnih postopkih. ZUP $\vee$ spremenjenem 63. členu določa, da lahko posamezniki ali pravne osebe oziroma organizacije vlogo poleg fizične (papirne) oblike vložijo tudi v elektronski obliki, ki je podpisana z varnim elektronskim podpisom s kvalificiranim potrdilom. Vloge se lahko vlagajo elektronsko ves čas tudi zunaj delovnega časa organa. Pomembno spremembo uvaja sprememba zakona na področju vročanja. Spremen-

3 Predvsem mislimo na 105. člen Zakona o pravdnem postopku (ZPP), ki ureja elektronsko poslovanje s strankami.

4 Nediskriminacija e-oblike je eno izmed načel Zakona o elektronskem poslovanju in elektronskem podpisu (ZEPEP).

5 Zakon o spremembah in dopolnitvah zakona o splošnem upravnem postopku - ZUP-C (Ur.I. RS, št. 73/2004). 
Pomembno spremembo uvaja sprememba zakona na področju vročanja. Spremenjeni 83. člen ZUP določa, da se dokumenti lahko vročajo tudi elektronsko, če stranka to želi izrecno ali če je stranka zahtevo za uvedbo postopka poslala v elektronski obliki. Opomniti je smiselno še na določila spremenjenega 82. člena, ki določajo, da imajo zainteresirane stranke pravico do pregleda dokumentov $\vee$ svoji zadevi kakor tudi pravico do obveščanja in spremljanja postopka $\vee$ informacijskem sistemu za obveščanje. ${ }^{6}$

Menimo, da bi morali o podobnih spremembah zakonodaje razmišljati tudi $v$ okviru ZPP, ki bi omogočile elektronsko vložitev, vročanje in spremljanje postopka, ki teče pred sodiščem. Z načelom nediskriminacije elektronske oblike sta pod določenimi pogoji $\vee$ ZPP izenačeni elektronska in pisna oblika, vsaj kar se tiče prejemanja dokumenta na sodišče, vendar kljub temu, da zakon minimalno omenja elektronsko obliko ali natančneje komunikacijsko tehnologijo, v zakonodaji o elektronsko podrtem poslovanju sodnega procesa ne moremo govoriti. Na sodiščih obstajajo nekateri interni produkti, ki omogočajo elektronsko podprto poslovanje znotraj sodišč (Brezovar 1997, str. 176), vendar so v razvoju oziroma so nezanesljivi ali nepopolni?

\section{Akcijski načrt in druge pravne e-storitve v Sloveniji}

V Akcijskem načrtu e-uprave do leta 2004, ki naj bi bil nadomeščen z novim načrtom, so bili predvideni cilji, e-storitve in naloge vzpostavitve e-uprave do konca leta 2004. Akcijski načrt je predvideval 15 področij, pri katerih so za vsako načrtovane posamezne e-storitve, ki so predvidene za prebivalce $(G 2 C)$, poslovne subjekte (G2B) in znotraj uprave (G2G). Eno izmed področij je tudi pravosodje (CVI 2004, str. 7-9).

Za pravosodje so bila navedena podpodročja: Potrdilo o nekaznovanju, Pravni informacijski sistemi, Registri in Informacijski sistemi za spremljanje sodnih postopkov. Na nekaterih podpodročjih so e-storitve že popolnoma vzpostavljene: npr. oddaja zahtevka izpisa o nekaznovanju, dostop do sodne prakse Vrhovnega sodišča, sodnega registra in elektronske zemljiške knjige ${ }^{\mathbf{8}}$.

6 Kot določa spremenjeni 5. odstavek 63. člena, bodo pogoji in način vložitve, vročanje ter organizacija za to predvidenega informacijskega sistema natančneje urejeni z vladno uredbo.

7 Po razgovorih z zaposlenimi na sodiščih se pogosto pojavljajo odpovedi informacijske tehnologije predvsem zaradi starosti programske in strojne opreme.

8 E-storitvi pridobitve potrdila o nekaznovanju in dostop do sodnega registra sta dostopni na: http://euprava.gov.si/, sodna praksa Vrhovnega sodišča in dostop do elektronske zemljiške knjige na: http://www.sodisce.si/. 


\section{Benjamin Lesjak \\ Uvajanje e-poslovanja na sodišče kot storitev e-uprave}

Na podpodročju Informacijskih sistemov za spremljanje sodnih postopkov, ki predvideva e-storitev Spremljanje pravdnih postopkov, ni zaslediti dejavnosti. Možnosti spremljanja pravdnega postopka je e-storitev, ki jo uvede sodišče, tako da zainteresiranim strankam omogoči dostop do sistema in vpogled $v$ določen pravdni proces. $V$ ta namen mora sodišče imeti informacijsko podprt proces, ki omogoča spremljanje dogodkov $v$ procesu, sodnih spisov in druge pripadajoče dokumentacije od prihoda $v$ sistem do arhiviranja ali druge oblike odhoda dokumentacije iz sistema ali zaključka aktivnosti.

Druge pravne storitve ali storitve $v$ okviru pravosodja, ki so na voljo $\vee$ Sloveniji slovenskim državljanom, so omejene predvsem na poizvedovanje za pravnimi informacijami in dostop do raznih obrazcev, ki jih je mogoče izpolniti ročno. Npr. na spletnih straneh Vrhovnega sodišča Republike Slovenije so dostopni obrazci, ki si jih stranke lahko natisnejo in izpolnijo same. To so predvsem obrazci v zvezi z vpisom ali spremembo podatkov $v$ sodni register (novi subjekti, spremembe, firma) in obrazci v zvezi z vpisi v zemljiško knjigo ali izbrisi iz nje. Prav tako je $\vee$ okviru državnega portala e-uprava ${ }^{9}$ naveden sklop življenjskih dogodkov, ki se nanašajo na družbo, državo in pravo, vendar kaj več od osnovnih informacij in zakonodaje, ki ureja posamezno področje, ni zaslediti. Opaziti pa je, da je področje upravnega postopka in upravnega spora veliko bolj prijazno in celovito urejeno, saj nas napoti na portale upravnih enot, ki ponujajo celovit nabor vprašanj in odgovorov $v$ zvezi s posameznim življenjskim dogodkom. $\vee$ večini drugih primerov, npr. kazenskem ali civilnem postopku, pa zgolj omenjata zakonodajo s področja.

$\checkmark$ Sloveniji so kot pravna e-storitev dobro razviti sistemi, ki omogočajo javnosti prost dostop do informacij javnega značaja, med katere spadajo tudi prečiščena besedila predpisov, predlogi, pravna praksa in druge pravne informacije ${ }^{\mathbf{1 0}}$. Spletne strani Registra pravnih predpisov Slovenije, Državnega zbora, Uradnega lista, Ustavnega in Vrhovnega sodišča" ter druge spletne strani predvsem državnih organov in organov javne uprave na lastnih spletnih straneh objavljajo številne pravne informacije, ki spadajo pod njihovo pristojnost. Pri tem je treba poudariti, da imamo v Sloveniji zelo močnega komercialnega ponudnika s tega področja.

Za razliko od storitev $v$ okviru prava ali pravdnega postopka, ki bi omogočale vpogled $v$ primer ali spremljanje primera na sodišču, oziroma dejavno poseganje $v$ sam postopek za pooblaščene osebe (npr. odvetnika stranke), so e-storitve e-uprave razvite do te mere, da omogočajo izvedbo celotne storitve po elektronski poti.

9 Naslov državnega portala e-uprava: http://e-uprava.gov.si

10 Podrobneje o obveznosti zavezancev in obsegu objavljanja informacij je zapisano v Zakonu o dostopu do informacij javnega značaja (ZDIJZ), ki je bil sprejet v letu 2003.

11 Naslovi naštetih spletnih strani: http://zakonodaja.gov.si/, http://www.dz-rs.si/, http://www.uradnilist.si, http://www.us-rs.si/.

\section{Uprava, letnik II, 2/2004}


Storitve so smiselno razporejene na tiste, ki omogočajo vpogled, in tiste, ki dejansko predstavljajo storitev bodisi za državljane, gospodarstvo in druge portale javne uprave. ${ }^{12}$

\section{Možne oblike uvajanja informacijske tehnologije na sodišča}

Za vzpostavitev e-poslovanja se med pravniki v splošnem pojavljajo specifične potrebe in oblike uporabe informacijske tehnologije. Susskind (1996, str. 149) navaja, da pravniki uporabljajo informacijsko tehnologijo $v$ več sklopih: za elektronsko komuniciranje, za ustvarjanje in upravljanje besedil, kot podporo pri sodnem procesu, kot sisteme za podporo lastnega znanja, za iskanje informacij in za upravljanje s sodnimi primeri (Case Management Systems). Omenjena tehnologija se uporablja tako, da se obstoječi načini dela avtomatizirajo ali da se s tehnologijo pride do inovacij na področju dela in se ustvari nov način dela in opravljanja nalog.

Podpora informacijske tehnologije $v$ sodnem procesu po Susskindu (1996, str. 166 in str. 2000, 246) obsega tri glavna področja: upravljanje in nadzor nad dokumentacijo na strani odvetnika pri zastopanju stranke; nadzor nad dokumentacijo in potekom postopka na sodišču; uporaba tehnologije na sodišču: osebni računalnik za sodnika, podpora pri urejanju zapisnika, prikaz dokumentacije za potrebe dokazovanja, grafični in video prikazi.

Susskind (2000, str. 136-149) našteva številne možne oblike uporabe informacijske tehnologije $\vee$ pravu, od katerih poudarjamo tiste, ki vzpostavljajo možnost e-poslovanja na sodišču in pomenijo podporo pri sodnem procesu. $V$ nadaljevanju bomo poskušali na kratko prikazati nekatere ideje, na kakšen način lahko pravniki in druge stranke, ki so dejavne na sodišču, uporabljajo informacijsko tehnologijo in elektronsko poslujejo.

\subsection{Pravniki na sodišču}

Za pravnike, ki delujejo na sodišču, med katere uvrščamo predvsem sodnike, odvetnike, tožilce in druge strokovne sodelavce sodišča, je smiselno vzpostaviti posebne spletne informacijske portale za pravne zadeve, ki se vodijo na sodišču od začetka do zaključka postopka na sodišču oz. arhiviranja. Tovrsten sistem omogoča elektronsko vlaganje, spremljanje, obveščanje zainteresiranih strank o posamezni

12 Vse storitve, ki jih je možno opraviti elektronsko, so dosegljive na spletni stran e-uprave: http://euprava.gov. si/e-uprava/portalStran.euprava?pageid=499 


\section{Benjamin Lesjak \\ Uvajanje e-poslovanja na sodišče kot storitev e-uprave}

zadevi, ki teče na sodišču. Uporabnikom je ob strogih varnostnih zahtevah omogočen dostop od koderkoli in kadarkoli.

Znotraj organizacije je z intranetom možna vzpostavitev sistema notranjih informacij. Ta sistem obsega številne pravniške izkušnje, znanja, ki jih pravniki pridobijo z leti službovanja, in jih imenujemo sistemi za upravljanje znanja. S pomočjo tovrstnega sistema pride do izmenjevanja znanja.

Z globalnostjo informacijske tehnologije se poraja nov mednarodni vidik sodelovanja med pravniki, ki lahko nemoteno komunicirajo prek sistemov za skupinsko delo. Nadgradnjo komuniciranja in sodelovanja med pravniki predstavljajo navidezni pravni timi, ki s pomočjo sistemov za skupinsko delo na daljavo delujejo kot ena organizacijska enota, čeprav so fizično ločeni. Tovrstna tehnologija lahko združi pravnike $v$ navideznem prostoru in velike pravne firme lahko pričakujejo resno konkurenco majhnih firm, ki bodo lahko povezovale in združevale talente, znanja in izkušnje.

Avtomatizirani sistemi za kreiranje dokumentov omogočajo odpravo rutinskih in enoličnih dokumentov s pomočjo predlog, ki so pripravljene vnaprej ali kreirane sproti prek vprašanj in odgovorov. Na podlagi vnesenih podatkov sistem ustvari želen dokument $v$ pravilni enotni obliki. Sistem ni namenjen samo pravnikom, temveč je smiseln tudi za druge pri pisanju dopisov s pravniško vsebino (npr. oporoke, preproste pogodbe, pritožbe, zahtevki, prošnje in druga pisanja).

Pravni diagnostični sistem je osnovan na ekspertnem sistemu, s katerim lahko sodnik pri sojenju na podlagi vnesenega opisa stanja prejme nekaj možnih smeri, kako naj $v$ določeni zadevi razsodi. Podatki se običajno vnašajo interaktivno $v$ obliki odgovorov na vnaprej pripravljena vprašanja, nato sistem analizira podrobnosti, na podlagi že vnesenih podatkov poda zaključke ali morebitne napotke za pomoč pri odločitvi. Sistem je zelo podoben diagnostičnim sistemom v medicini. Dejstvo, da je pravni sistem zelo kompleksen, onemogoča vzpostavitve sistema, ki bi lahko v celoti nadomestil sodnika, zato je tovrsten sistem je možno vzpostaviti le za preprostejše odločitvene situacije.

Sodne odločbe, ki jih sodniki pišejo v elektronski obliki (morebiti celo narekujejo s pomočjo sistema za prepoznavo govora), se lahko objavljajo tudi na internetu. Sistem bi omogočal takojšen dostop do pravne prakse drugim pravnikom, po možnosti bi se dokumenti opremili s sodnikovim komentarjem in ključnimi besedami. Po našem mnenju bi bilo zaradi varovanja podatkov smiselno ustvariti sistem, ki bi samodejno preiskal dokument in iz njega izbrisal osebne podatke.

Z intenzivnejšim pojavom informacijske tehnologije je pričakovati povsem nove vloge pravnikov. Pravniki se bodo pojavili v vlogi »inženirja» oziroma svetovalca, ki bodo zaradi specifične uporabe prava $\vee$ povezavi z informacijsko tehnologijo prevajali in razlagali pravne informacije nepravnikom. Obenem bodo pravniki zagotavljali nepravnikom verodostojnost sistemov in storitev, ki jih bodo slednji uporabljali.

\section{Uprava, letnik II, 2/2004}




\section{Benjamin Lesjak \\ Uvajanje e-poslovanja na sodišče kot storitev e-uprave}

\subsection{Informacijska tehnologija v okviru sodišča samega}

S pomočjo poenotenega sistema upravljanja sodnih primerov lahko vsi individualni sistemi delujejo kot en sam sistem drug poleg drugega. Sodniki, pravni svetovalci, odvetniki, administrativno osebje in stranke lahko spremljajo potek postopka na sodišču prek enotnega sistema in prek enega vstopnega mesta. Dokumentacija, ki se nanaša na posamezen primer, je tako pripeta elektronskemu spisu, dostopna upravičenim uporabnikom in popolnoma skladna $v$ primeru prehoda z enega sodišča na drugo.

Ustvarjanje zapisnikov s pomočjo snemanja, tipkanja ali podobne tehnike, ki jih poznamo danes, bo $\mathrm{v}$ prihodnosti nadomeščeno $\mathrm{s}$ sistemi za prepoznavo govora, $\mathrm{ki}$ so opremljeni s širokim slovarjem in predvsem neodvisni od govornika. Na ta način bodo vsa dogajanja $v$ sodni dvorani zapisana elektronsko, prav tako morebitna zaslišanja in druge obravnave. $V$ mislih imamo izboljšane elektronske zapisnike, ki so po možnosti obogateni tudi z glasovnim in slikovnim gradivom. Najpomembnejša pridobitev je gotovo sistem za prepoznavo govora, ki bi na podlagi nareka takoj ustvaril končni zapisnik $v$ papirni ali elektronski obliki.

Zaslišanja in druga procesna dejanja na daljavo so lahko omogočena z videokonferenčno opremo kot oblika podajanja argumentov tožeče stranke na obrambo tožene stranke ali kot oblika zagovora pred sodiščem v elektronski obliki (po načelu kot odgovor pri elektronski pošti) ali v obliki pogajanj na spletu $v$ primeru poravnave ali celo skrivnih elektronskih pogajanj med strankama.

Vse našteto bo uveljavljeno predvsem zaradi tega, da bodo stranke lahko opravljale procesna dejanja kljub temu, da ne bodo fizično navzoče. V kazenskih postopkih se lahko s pomočjo videokonferenčne opreme lahko zavaruje pričanje anonimnih prič $^{\mathbf{1 3}}$.

Na spodnji sliki prikazujemo statično sliko ideje uvajanja informacijske tehnologije na sodišču, na kateri so v okviru informacijskega portala za pravne zadeve združeni različni podsistemi, ki uvajajo nove načine dela: od avtomatiziranega kreiranja dokumentov, zajemanja znanja znotraj intraneta, uvajanja pravnega diagnostičnega sistema, videokonferenčnega povezovanja oddaljenih lokacij in baz podatkov do najbolj pomembnega sistema za upravljanje sodnih primerov. Relacije med sistemi namenoma niso točno določene, prav tako niso zajeti akterji, ki so vključeni, kajti v enoten sistem so možna vključevanja od zunaj (npr. videokonference ali upravljanje s sodnimi primeri), prav tako mora sistem omogočati povezovanje z drugimi sistemi in uvajanje novih idej ter podsistemov $v$ obstoječem.

$13 \vee$ Sloveniji je bila v juliju 2004 opravljena prva tovrstna videokonferenca na kazenskem sodišču v Murski soboti http://24ur.com/naslovnica/slovenija/20040714_2043226.php in

http://www.rtvslo.si/modload.php?\&c_mod=rnews\&op=sections\&func=read\&c_menu=1\&c_id=41626

Uprava, letnik II, 2/2004 
Benjamin Lesjak

Uvajanje e-poslovanja na sodišče kot storitev e-uprave

Slika 1: Ideja uvajanja informacijske tehnologije na sodišče

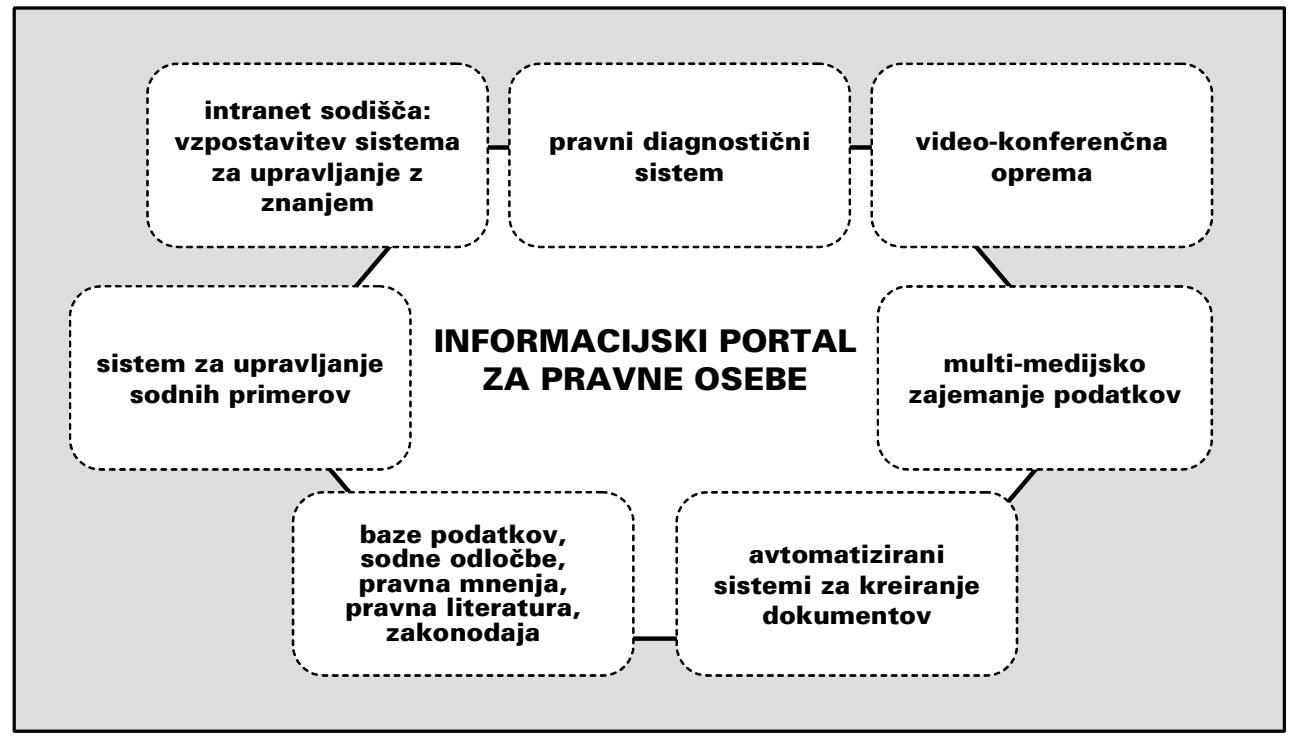

\section{Raziskava med slovenskimi pravniki}

V mesecu decembru 2003 smo opravili raziskavo med slovenskimi pravniki, ki že uporabljajo informacijsko tehnologijo (Lesjak 2004, str. 45). Poskušali smo ugotoviti, v kolikšni meri jo uporabljajo in kakšno mnenje imajo o možnostih uvajanja eposlovanja na sodišča, tako da bi sodišča uvedla možnost elektronskega vlaganja dokumentov za potrebe procesa pred sodiščem. Obenem smo sodelujočim v anketi ponudili preizkus prototipne rešitve, ki omogoča izvedbo postopka med strankama pred sodiščem s pomočjo sodobne tehnologije, tako da si stranki elektronsko izmenjujeta dokumentacijo s sodiščem. Prototipno rešitev smo s pomočjo njenega preizkusa ovrednotili v realnem okolju z namišljenim primerom.

\subsection{Vzorec}

Anketo smo izvedli s pomočjo vprašalnika po e-pošti, ki smo ga v dveh sklopih poslali na približno 800 elektronskih naslovov slovenskih sodnikov, odvetnikov in tistih pravnikov (univerzitetnih profesorjev oz. docentov ali asistentov), ki so zaposleni na pravnih fakultetah. Podatke o naslovih, na katere smo naslovili anketni vprašalnik, smo pridobili s pomočjo Poslovnega informatorja Republike Slovenije 2003. Nekatere 


\section{Benjamin Lesjak \\ Uvajanje e-poslovanja na sodišče kot storitev e-uprave}

podatke smo preverili tudi pri pristojnih uradnih ustanovah, to so Ministrstvo za pravosodje, Odvetniška zbornica Republike Slovenije in pri pravnih fakultetah ${ }^{\mathbf{1 4}}$, nekatere smo poiskali na svetovnem spletu s pomočjo iskalnikov. V Sloveniji je bilo $\checkmark$ času raziskave okoli 900 sodnikov $^{\mathbf{1 5}}$, ki delujejo na vrhovnem, višjih, okrožnih in okrajnih sodiščih ter na delovnih in socialnih sodiščih ter upravnem sodišču. Po podatkih Odvetniške zbornice je bilo v Sloveniji 25. 9. 2003 registriranih 947 odvetnikov. Od navedene številke nam je uspelo poiskati 239 naslovov. Na Pravni fakulteti Univerze v Mariboru je zaposlenih okoli 40 ter na Pravni fakulteti v Ljubljani okoli 50 pravnikov kot univerzitetnih profesorjev oz. docentov ali asistentov ${ }^{\mathbf{1 6}}$.

Na anketo se je odzvalo 163 slovenskih pravnikov, od katerih je bilo največ anketirancev sodnikov oziroma sodnic (36 \%), tesno so jim sledili odvetniki oziroma odvetnice $(35,4 \%)$, najmanj je bilo univ. dipl. pravnikov oziroma pravnic - zaposlenih na pravni fakulteti $(13,7 \%)$ ter nekoliko več opredeljenih pod drugi poklici $(14,9 \%)$.

\subsection{Opremljenost in uporaba informacijske tehnologije}

Glede uporabe računalnika $v$ službi in porabe časa na internetu $v$ službi je velika večina $(98,8 \%)$ slovenskih pravnikov odgovorila, da $\vee$ službi uporablja računalnik, ki je priključen na internet, kar je glede na to, da smo anketo izvedli prek e-pošte, pričakovano. Glede časa, ki ga anketiranci porabijo za delo z internetom $\vee$ službi, je več kot polovica anketirancev $(57,7 \%)$ odgovorila, da porabi do 1 uro, odstotek se je prepolovil pri tistih, ki porabijo več kot 1 in do 2 uri. Odstotki anketirancev, ki porabijo še več časa za delo z internetom v službi, so še nižji.

Zaznali smo, da skoraj $90 \%$ anketiranih uporablja svetovni splet. Med uporabniki svetovnega spleta smo ugotovili, da 93,3 \% slovenskih pravnikov uporablja svetovni splet za iskanje sodne prakse, $91 \%$ za iskanje zakonodaje in 83,6 \% za iskanje pravne literature. Visoki odstotki pri navedenih področjih so smiselni, saj pravnik potrebuje pravne informacije za vsakodnevno delo. Zelo vzpodbuden je podatek, da e-bančništvo uporablja kar 46,3\% anketiranih, med katerimi je dobra polovica samo odvetnikov, prav tako je vzpodbuden podatek, da okoli 16,4\% anketiranih uporablja svetovni splet za e-nakupe.

14 Naslov spletne strani Ministrstva za pravosodje: http://www.sigov.si/mp/ (15.10. 2003), Odvetniške zbornice: http://www.odv-zb.si/ (15.10. 2003) in spletnih strani obeh pravnih fakultet: http://www.pf.unimb.si (15.10. 2003) in http://www.pf.uni-lj.si (15.10. 2003).

15 Podatek pridobljen na portalu slovenskih sodišč. http://www.sodisce.si (1.11. 2003)

16 Podatek pridobljen na podlagi pogovorov z administrativnim osebjem pravnih fakultet. 
Benjamin Lesjak

Uvajanje e-poslovanja na sodišče kot storitev e-uprave

\section{Preglednica 1: Uporaba računalnika in poraba časa za delo}

$z$ internetom v službi

\begin{tabular}{|c|c|c|c|}
\hline & & pogostost & delež $\vee \%$ \\
\hline $\begin{array}{l}\text { Ali v službi uporabljate } \\
\text { osebni računalnik, ki je } \\
\text { priključen na } \\
\text { internet? }\end{array}$ & $\begin{array}{l}\mathrm{Ne} \text {, ne uporabljam računalnika. } \\
\text { Da, uporabljam računalnik, vendar ni } \\
\text { priključen na internet. } \\
\text { Da, uporabljam računalnik, ki je priključen } \\
\text { na internet. }\end{array}$ & $\begin{array}{c}1 \\
1 \\
161\end{array}$ & $\begin{array}{l}0,6 \\
0,6 \\
98,8\end{array}$ \\
\hline $\begin{array}{l}\text { Koliko časa v službi } \\
\text { porabite za delo z } \\
\text { internetom? }\end{array}$ & $\begin{array}{l}\text { Nič. } \\
\text { Do } 1 \text { ure. } \\
\text { Več kot } 1 \text { in do } 2 \text { uri. } \\
\text { Več kot } 2 \text { in do } 5 \text { ur. } \\
\text { Več kot } 5 \text { ur. }\end{array}$ & $\begin{array}{l}7 \\
94 \\
44 \\
13 \\
5\end{array}$ & $\begin{array}{l}4,3 \\
57,7 \\
27,0 \\
8,0 \\
3,1\end{array}$ \\
\hline
\end{tabular}

Preglednica 2: Za kaj uporabljajo anketiranci svetovni splet?

\begin{tabular}{|l|l|c|c|}
\hline \multicolumn{2}{|l|}{} & $\begin{array}{c}\text { število } \\
\text { odgovorov }\end{array}$ & $\begin{array}{c}\text { delež v } \\
\%\end{array}$ \\
\hline $\begin{array}{l}\text { Da, uporabljam } \\
\text { svetovni splet za: }\end{array}$ & $-\quad$ iskanje zakonodaje & 122 & 91,0 \\
& $-\quad$ iskanje sodne prakse & 125 & 93,3 \\
& $-\quad$ iskanje pravne literature & 112 & 83,6 \\
& $-\quad$ iskanje drugih informacij v zvezi s poklicem & 86 & 64,2 \\
& $-\quad$ obiskovanje forumov & 17 & 12,7 \\
& $-\quad$ komuniciranje (npr. IRC, Yahoo Messenger, \\
& ICQ) & 39 & 44,0 \\
& $-\quad$ e-bančništvo & 62 & 22,4 \\
& $-\quad$ poslovanje z e-upravo & 11 & 46,3 \\
& $-\quad$ e-nakupe & 22 & 16,4 \\
\hline
\end{tabular}




\subsection{E-vložitev}

Med anketiranci smo ugotovili, da dobra polovica ne pozna možnosti e-vložitve dokumentov na sodišče. Glede na poklic je e-vložitev bolj poznana med sodniki (61 \%) kot med odvetniki, kjer pozna možnost elektronske vložitve le $40 \%$, ali med pravniki na pravnih fakultetah (33\%). Visok odstotek pri sodnikih morebiti izhaja iz dejstva, da se na sodišču e-vložitev dokumentov mora uvesti in so zato o tem na sodiščih bolj seznanjeni.

Možnost uvedbe e-poslovanja na sodišče ugotavljamo z dveh vidikov: kaj si anketirani mislijo, da bo na področju elektronskega poslovanja resnično uvedeno oziroma doseženo, ter kakšna pričakovanja oziroma želje imajo glede uvedbe novih storitev, kar bi predvidoma kasneje sami uporabljali. Upoštevaje, če je pričakovati, da bi lahko v roku dveh let zainteresirani že lahko vložili dokument na sodišče v elektronski obliki, nekoliko manj od polovice anketiranih meni, da bo to mogoče, na drugi strani jih več kot polovica tega ne ve oziroma meni, da to ne bo mogoče. Lahko trdimo, da anketirani ne verjamejo izrazito močno, da bo resnično $v$ dveh letih že možno na slovensko sodišče vložiti dokument elektronsko.

Ko smo merili pričakovanje, $v$ kolikšni meri bi sodišča morala zainteresiranim omogočiti elektronsko vložitev, smo opazili zelo visoko strinjanje oziroma visoko stopnjo pričakovanja. Skupno se skoraj $90 \%$ anketiranih bolj ali manj strinja, naj sodišča uvedejo možnost elektronske vložitve. Možno je, da bi potem to storitev prav tako množično tudi uporabljali. Očitno je pripravljenost elektronsko poslovati s sodiščem pri anketiranih na zelo visoki ravni. Ob tem bodo pravniki gotovo morali osvojiti nove veščine in znanja, vendar iz visoke podpore lahko sklepamo, da so navdušeni nad možno uporabo novih storitev.

Slika 2: Sodišča v Sloveniji naj strankam, ki to želijo, omogočijo možnost elektronske vložitve vlog

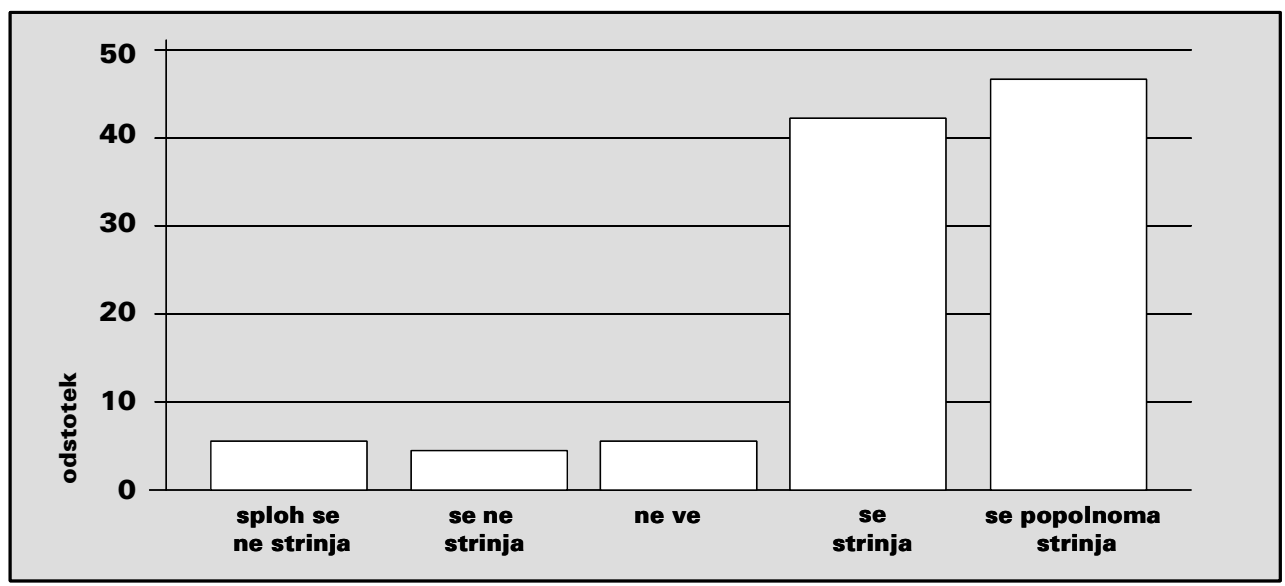

Uprava, letnik II, 2/2004 


\section{Benjamin Lesjak \\ Uvajanje e-poslovanja na sodišče kot storitev e-uprave}

Ob iskanju vzrokov za tako visoko pričakovanje anketiranih, naj sodišča uvedejo možnost elektronske vložitve, bi to lahko bila pospešitev postopka na sodišču ali zmanjšanje stroškov poslovanja. Slaba polovica anketirancev se bolj ali manj strinja, da bo elektronska vložitev pospešila postopek. Nekoliko več, slabi dve tretjini anketirancev, se bolj ali manj strinjata, da bo elektronska vložitev vlog na sodišče zmanjšala stroške poslovanja. Slednje nakazuje močnejšo podporo pocenitvi poslovanja. Torej anketirani pravniki bolj verjamejo $\vee$ znižanje stroškov kot $v$ samo pospešitev postopka.

\section{Slika 3: Elektronska vložitev vlog na sodišče bo pospešila} postopek na sodišču

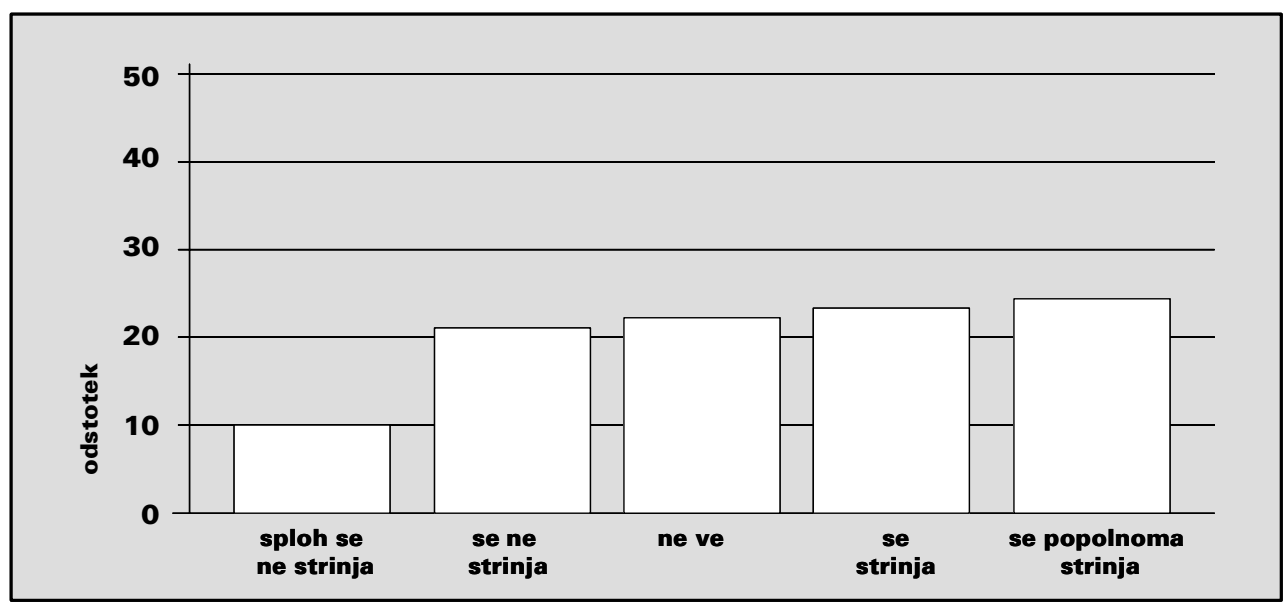

Slika 4: Elektronska vložitev vlog na sodišče bo zmanjšala stroške poslovanja

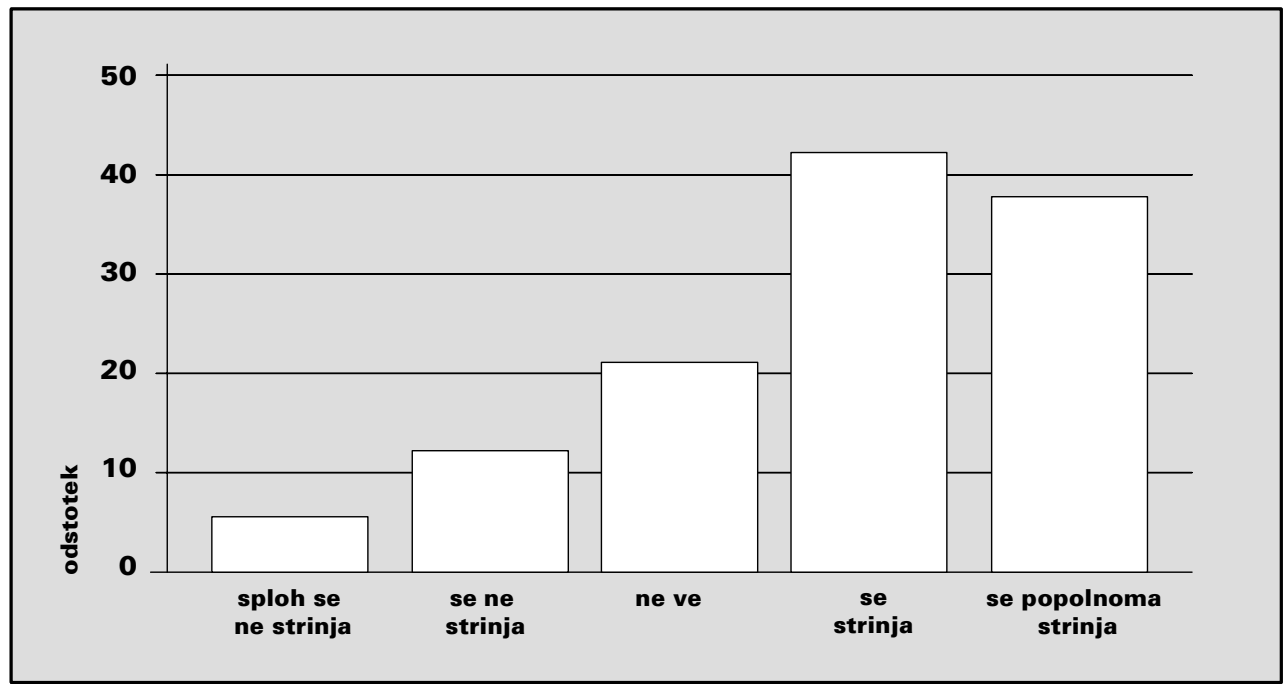


Ob uvajanju elektronske vložitve se pojavlja vprašanje, kako je s prejemanjem sodnih pisanj po e-pošti, torej z možnostjo elektronske vročitve. Več kot tri četrtine anketirancev bolj ali manj meni, naj sodišča zainteresiranim strankam, ki to želijo, omogočijo prejemanje sporočil sodišča elektronsko. Glede vročanja sodnih pisanj po e-pošti meni skupaj več kot polovica anketiranih, da bo to prispevalo k pospešitvi, kar je več kot $v$ primeru elektronske vložitve. Ponovno pa so bolj prepričani, da bi pošiljanje sodnih pisanj po e-pošti prispevalo $k$ zmanjšanju stroškov, vendar nekoliko manj kot v primeru elektronske vložitve.

Slika 5: Sodna pisanja naj sodišče strankam, ki to izrecno želijo, pošilja po e-pošti (možnosti e-vročitve)

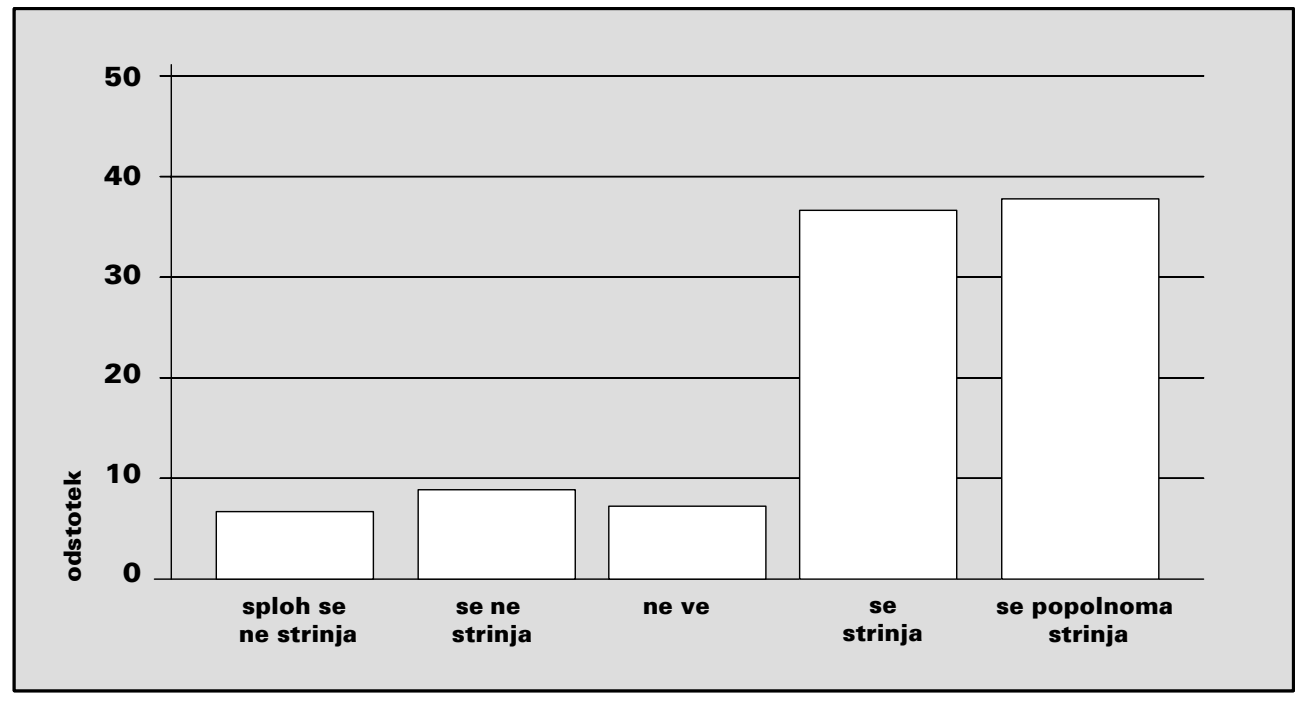

Povsem obrnjena situacija je glede možnosti, da bi v prihodnjih dveh letih speljali sodni postopek brez papirja in izključno $v$ elektronski obliki. Skupno se kar dve tretjini anketirancev bolj ali manj ne strinjata s tem, pri čemer se jih več popolnoma ne strinja. Po njihovem mnenju torej ni pričakovati izvedbe sodnega postopka povsem brez papirja. Lahko trdimo, da je elektronsko vodenje in podpora celotnega postopka z elektronsko obliko še dokaj daleč. Zelo malo anketirancev se namreč strinja s tem, le okoli $5 \%$. Iz navedenega lahko sklepamo, da pravniki v veliki meri bolj zaupajo papirni obliki in si postopka $\vee$ elektronski obliki niti ne morejo dobro predstavljati. Ampak glede na visoko podporo za uvedbo elektronske vložitve in prejemanja sodnih pisanj $\vee$ elektronski obliki bi lahko pričakovali večjo podporo vodenju postopka $v$ izključno elektronski obliki. Očitno je vezanost na papir tako močna, da se papirni obliki ne bomo mogli izogniti, in bo $v$ sodstvu navzoča ves čas. Ob trditvi, da bo uvedba elektronskega poslovanja na sodišču vplivala na 
Benjamin Lesjak

Uvajanje e-poslovanja na sodišče kot storitev e-uprave

učinkovitost sodnikov, se anketirani nagibajo bolj k temu, da elektronsko poslovanje ne bo vplivalo na učinkovitost sodnikov, oziroma jih večina odgovarja, da ne ve. Sodeč po mnenjih anketiranih pravnikov prav tako ni pričakovati zmanjšanja sodnih zaostankov zaradi uvedbe elektronskega poslovanja.

Slika 6: V prihodnjih dveh letih bo mogoče speljati sodni postopek brez papirja, tako da bo celoten postopek tekel $v$ elektronski obliki

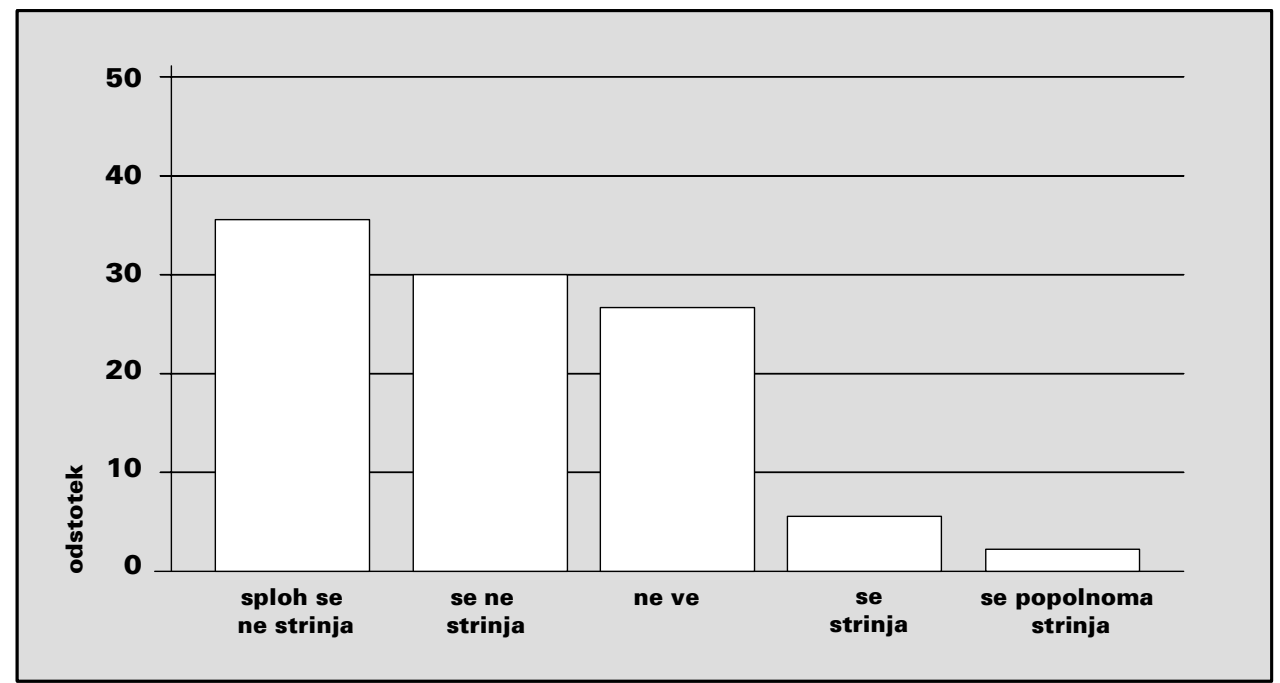

\subsection{Prototipna rešitev}

Udeležencem iz ankete, ki so izkazali pripravljenost za nadaljnje sodelovanje, smo po opravljeni anketi poslali vabilo za preizkus prototipne rešitve, ki omogoča elektronsko vložitev dokumentov na sodišče, vodenje evidence primerov in vodenje evidence strank. $\vee$ preizkusu so sodelovale trojice po dva odvetnika in en sodnik.

Odvetnikom je s prototipno rešitvijo omogočeno, da lahko od koderkoli vložijo za svojo stranko na sodišče želen dokument v elektronski obliki. Obenem lahko na enem mestu vodijo evidenco lastnih primerov, $v$ katerih sodelujejo kot odvetnik bodisi tožeče ali tožene stranke. Ob vsakem primeru imajo vpogled na vse dejavnosti in procesna dejanja, ki so se odvijala v zvezi z zadevo, ter vso dokumentacijo $\vee$ elektronski obliki. Sodniki imajo s prototipno rešitvijo popoln pregled nad primeri, $v$ katerih sodijo. Obenem lahko odrejajo razpošiljanje vloženih dokumentov in vabil sodišča. Možnosti vpogleda $v$ lastne zadeve imajo tudi stranke, ki jim je omogočen le vpogled, na kateri točki se postopek nahaja, in pregled vložene dokumentacije, vendar $v$ preizkusu niso sodelovale. Glavni namen preizkusa ni bil $v$ pravnem reševanju problema, temveč izpeljava celotnega postopka pred sodiščem 
$\checkmark$ elektronski obliki. Na vabilo se je odzvalo 21 udeležencev, ki so ob koncu preizkusa izpolnili vprašalnik, s pomočjo katerega smo ovrednotili prototipno rešitev ${ }^{\mathbf{1 7}}$.

Udeleženci so $v$ večini izkazali zadovoljstvo z vzorcem $(4,14)$, uporabnostjo prototipne rešitve $(4,1)$ in preglednostjo nad podrobnostmi posamezne zadeve $(4,19)$. Ravno preglednost nad podrobnostmi posamezne zadeve, ki teče na sodišču, je najbolj pomemben del prototipne rešitve, ker predstavlja elektronski vpisnik, kjer se zbirajo vsi dokumenti, ki jih stranke vlagajo, in omogoča vpogled v dokumentacijo posamezne zadeve. Udeleženci so se bolj ali manj strinjali, da bi z določenimi popravki bila možna uporaba prototipne rešitve $v$ realnem postopku pred sodiščem $(3,95)$. Opozarjali so, da bi za končno rešitev morali izboljšati varnost prototipne rešitve in rešiti pravna vprašanja iz neurejene zakonodaje. Predpostavljamo, da bi bili udeleženci pripravljeni popravljeno rešitev uporabljati.

Udeleženci so se strinjali, da je prejemanje obvestil o zadevi, ki je tekla na sodišču, smiselno (3,9); namreč ob vsaki spremembi v zvezi z vodeno zadevo so bili obveščeni po e-pošti in so lahko ustrezno reagirali. Iz navedenega lahko sklepamo, da bi za stranke, ki poslujejo na sodišču, bila smiselna uvedba storitve sporočanja oziroma obveščanja prek e-pošte o zadevi, ki teče na sodišču in v kateri je stranka udeležena.

\section{Slika 7: Vzorec prototipne rešitve (Vložitev dokumenta)}

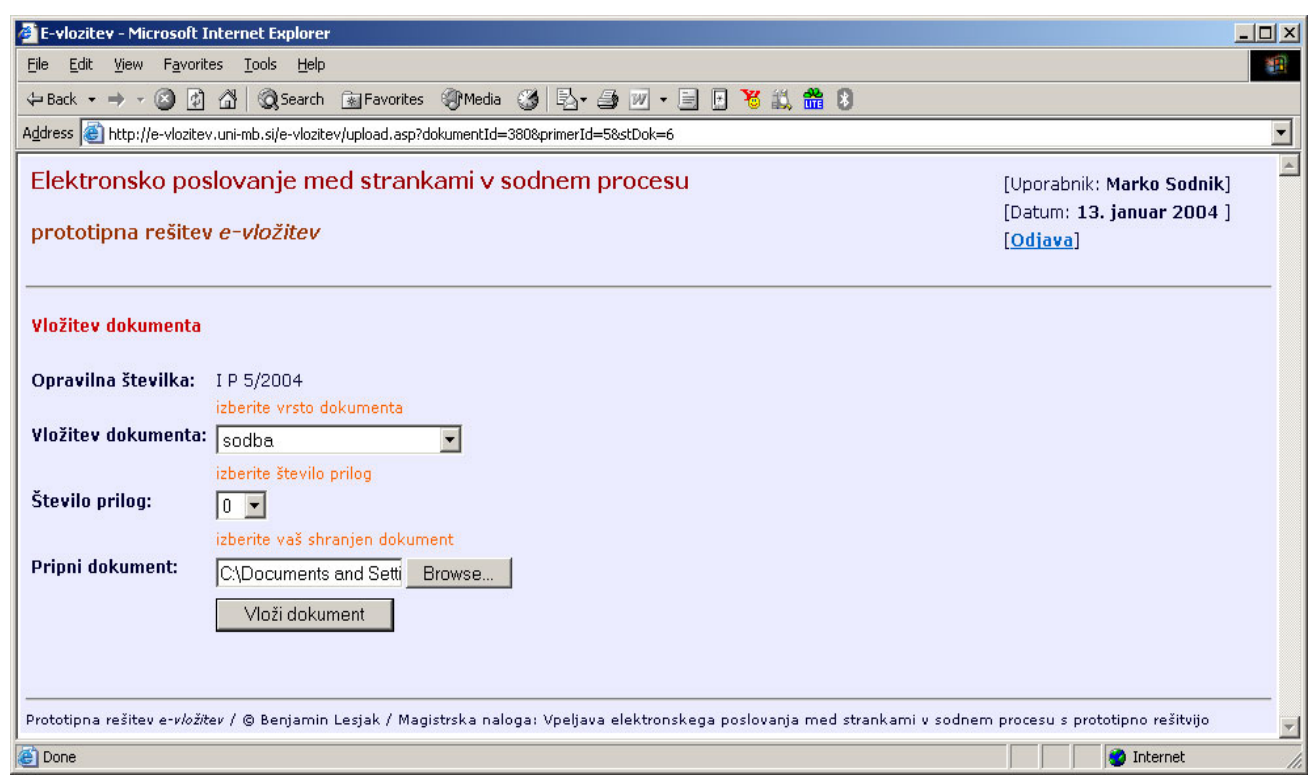

$17 \mathrm{~V}$ nadaljevanju v oklepajih navajamo srednje vrednosti odgovorov anketirancev, v kolikšni meri so se strinjali s trditvijo o prototipni rešitvi. 


\section{Benjamin Lesjak \\ Uvajanje e-poslovanja na sodišče kot storitev e-uprave}

\section{Slika 8: Vzorec prototipne rešitve (Prikaz podrobnosti primera - elektron- ski spis o zadevi na sodišču)}

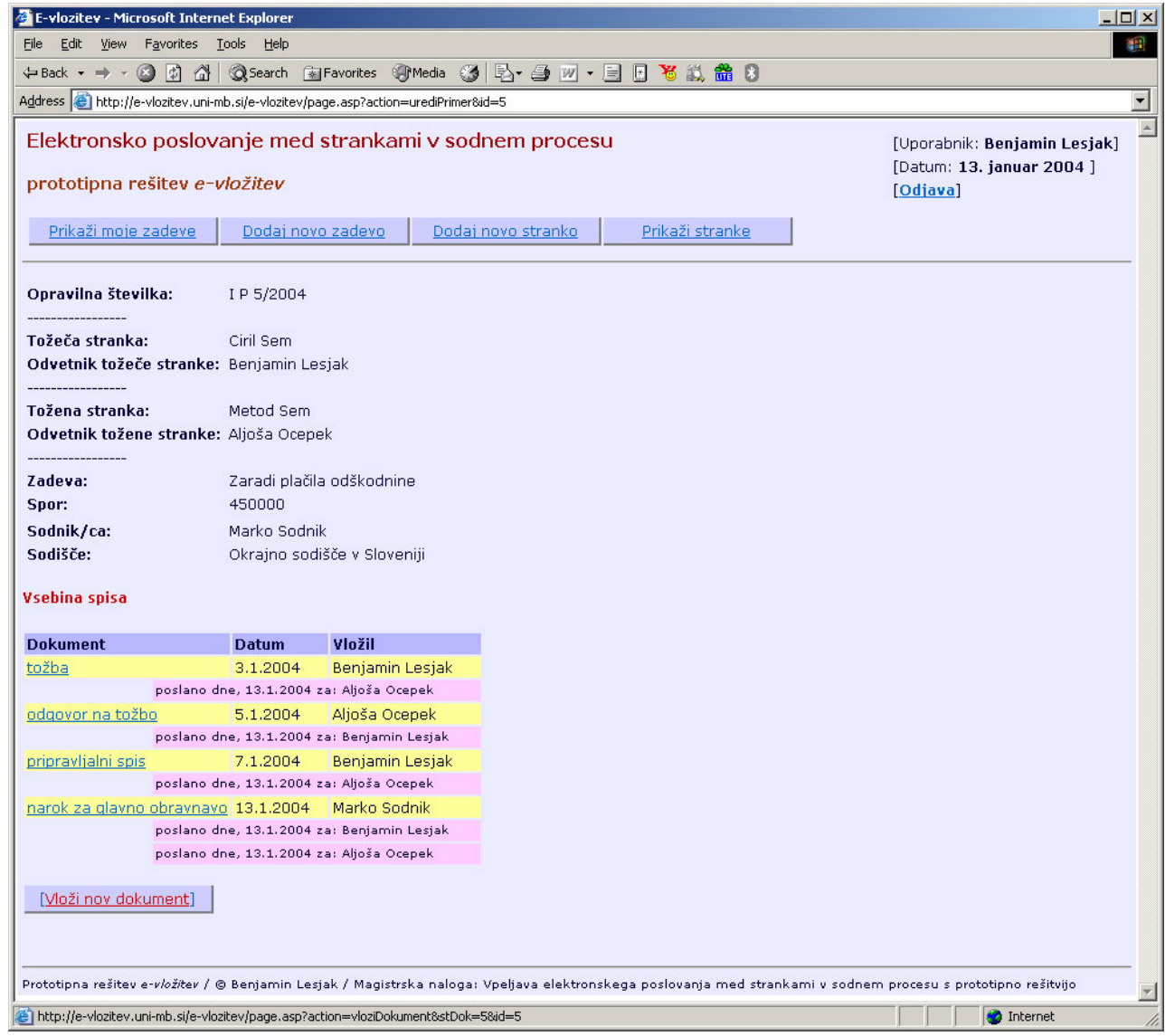

\section{Zaključki}

Morebiti do uvedbe e-poslovanja na sodišča v Sloveniji ali vsaj uvedbe možnosti elektronske vložitve niti ni tako daleč, če bi upoštevali predloge Akcijskega načrta, ki je predvideval e-storitev spremljanja pravdnega postopka na sodišču. Glede na odzive anketiranih slovenskih pravnikov lahko povzamemo, da so pripravljeni na elektronsko poslovanje s sodiščem, prav tako lahko vidimo, da so njihova pričakovanja visoka. Smeri razmišljanja ob uvajanju elektronskega poslovanja in elektronskih pravnih storitev tečejo $\vee$ nekaj smereh: zagotavljanje varnosti poslovanja, togost sodišč pri uvajanju novosti in zakonodaja.

Kljub optimistično naravnanim rezultatom moramo pri uvajanju e-poslovanja in e-storitev na sodišču upoštevati tudi druge komponente, predvsem varnost, ki je 
doslej nismo omenili. Treba je zagotoviti visoko stopnjo varnosti, kamor spada uporaba digitalnih potrdil, elektronskih podpisov, ki zagotavljajo identifikacijo uporabnika, avtentičnost, verodostojnost, nezatajljivost in celovitost podatkov, ki jih uporabnik elektronsko podpiše. Slednjih vidikov pri razvoju prototipne rešitve nismo upoštevali, vendar nanje opozarjamo.

Ker so sodišča zelo toge ustanove, $v$ katerih se novosti uvajajo zelo počasi ali sploh ne, bo zelo težko uvesti elektronsko poslovanje splošno na vsa slovenska sodišča. Po našem mnenju bi morali možnost elektronske vložitve omogočiti sprva na nekaterih zainteresiranih manjših sodiščih in dobro prakso počasi uvajati na druga sodišča. Pri tem bi nujno morali upoštevati možnosti za tiste, ki želijo poslovati s sodiščem še vedno $v$ fizični obliki in prejemati vloge $v$ elektronski ali papirni obliki. Sodišča v Sloveniji (Vrhovno sodišče) imajo dobro vzpostavljene sisteme za posredovanje informacij, predvsem dostop do pravne prakse, registrov in nasploh dostop do zakonodaje, ampak na tej ravni se ponudba ne sme končati, temveč morajo sodišča ponujeno informacijo nadgraditi $\vee$ obliki resničnih storitev, kot so uporabniku prijazni elektronski pravni vodiči (po sistemu najbolj pogostih vprašanj ali življenjskih primerov), možnost elektronskega vlaganja zahtevkov, prejemanje obvestil po e-pošti ali celo vzpostavitve ekspertnih sistemov kot pomoč pri delu.

Navsezadnje pa je treba upoštevati razvoj $\vee$ okviru procesne zakonodaje, ki mora v obstoječe poslovanje vključiti možnost e-poslovanja. Pojavlja se vprašanje: Ali bomo kot državljani oz. kot udeleženci $v$ sodnem postopku lahko prejeli sporočila sodišča po e-pošti? Z razvojem e-uprave in informatizacijo sodstva $v$ Sloveniji lahko $\vee$ prihodnosti na teh področjih gotovo pričakujemo spremembe. Vspodbudne spremembe vnašajo $\vee$ naš pravni sistem spremembe ZUP, ki omogoča elektronske vloge in elektronsko vročitev upravnih pisanj. Morebiti ideja, da sta naslov elektronske pošte in naslov stalnega oziroma začasnega prebivališča izenačena, ni tako daleč in bomo lahko uradno prejeli sodna pisanja tudi na elektronski poštni predal.

Benjamin Lesjak je diplomiral na Pravni fakulteti Univerze v Mariboru, kjer je zaposlen in izvoljen $\checkmark$ naziv asistenta za predmetno področje Pravna informatika. Magistriral je na Fakulteti za organizacijske vede Univerze $v$ Mariboru. Področja raziskovanja obsegajo teme pravne informatike, uporabe sodobnih tehnologij, uvajanja e-poslovanja in upravljanja z znanjem v pravu oziroma pravosodju. 


\section{Benjamin Lesjak \\ Uvajanje e-poslovanja na sodišče kot storitev e-uprave}

\section{Literatura in viri}

- Brezovar, R. (1997): Računalniška arhitektura informacijskih sistemov sodišč, Informatika v državnih organih - INDO 1997, Vlada RS, str 172-178

- Clarke, R: (2000): Roger Clarke's Electronic Commerce Pages, dostopno: http://www.anu.edu.au/people/Roger.Clarke/EC/ (10.5.2004).

- $\quad$ CVI (2004): Akcijski načrt e-uprave do leta 2004, Verzija 1.4« Ljubljana: Center vlade RS za informatiko, dostopno: http://www.cvi.si/cvi/slo/vodstvo/akcijski_nacrt_e-uprave_1.4.doc (1.2.2005).

- $\quad$ Galič, A., Ude, L. (2003): Zakon o pravdnem postopku, Založba Uradni list Republike Slovenije, Ljubljana.

- Gričar, J. (1997): Odprta vprašanja in smernice uvajanja elektronskega poslovanja v malih in srednje velikih podjetjih, Organizacija, letnik 31, številka 5, str. 245 - 253.

- Lesjak, B. (2004): Uvajanje e-poslovanja med strankami na sodišču s prototipno rešitvijo, magistrsko delo, Univerza v Mariboru, Fakulteta za organizacijske vede.

- McMillan, J., Douglas, W. and Webster, L. (1998): A Guidebook for Electronic Court Filing, dostopno: http://www.ncsc.dni.us/NCSC/TIS/TIS99/electr99/Guidebook/HTML/EfileWest.htm (1.7.2004)

- $\quad$ Susskind, R. (1996): The Changing Law - Facing the Challanges of Information Technology, Oxford University Press, New York.

- $\quad$ Susskind, R. (2000): Transforming the Law: Essays on Technology, Justice and the Legal Marketplace, Oxford University Press, New York.

- Toplišek, J. (1998): Elektronsko poslovanje, Atlantis, Ljubljana.

- Ude, L. (2002): Civilno procesno pravo, Uradni list, Ljubljana.

- Zakon o dostopu do informacij javnega značaja - ZDIJZ (Ur.I. RS, št. 24/2003)

- Zakon o elektronskem poslovanju in elektronskem podpisu - ZEPEP (Ur.I. RS, št. 98/2004).

- Zakon o pravdnem postopku - ZPP (Ur.I. RS, št. 36/2004).

- Zakon o splošnem upravnem postopku - ZUP (Ur.I. RS, št. 80/1999, 70/2000, 52/2002, 73/2004) 


\section{SUMMARY \\ Adopting E-business at Court as Service of E-government}

\section{Introduction}

E-business at court may be conditionally considered as e-business of G2C (government to citizen) or G2B (government to business), but we have to define letter $G$ in a wider sense, for instance: state or state agency, because courts are under judicial power. Nevertheless, in the Republic of Slovenia the most activities concerning e-business at court are taken at e-government projects. Electronic filing, which can be considered as a start of development of e-business at court, is defined as the process of transmitting documents and other court information to the court through an electronic medium, rather than on paper. Electronic filing enables people get more of their work done with their PCs, send and receive documents, pay filing fees, notify other parties, receive court notices, and retrieve court information.

E-business between parties at court may be defined as a communication/collaboration process with the court, where information and services are exchanged, delivered and paid with use of information technology from start to end of a trial at court.

The purpose is to find out if Slovenian civil procedure legislation allows filing or receiving court documents electronically. Other purposes of the article are to present the Action Plan eGovernment Up to 2004; to post some ideas, how judges, lawyers, and jurists in general can use information technology and to present findings of a survey among jurists on the use of information technology and e-business at court.

\section{Legislation basis of e-business at judicature}

Slovenian Civil Procedure Act partly allows filing a document to court electronically, but it is even harder to officially receive a document from court; nevertheless this has never been done in praxis. Recent changes in General Administrative Procedure Act allowed filing or handing the document electronically, therefore we suggested similar changes in Civil Procedure Act, too.

\section{Action plan and other legal electronic services in Slovenia}

Development of e-government in Slovenia is defined in "Action Plan eGovernment Up to 2004". One of the segments in Action Plan that concerns 
Benjamin Lesjak

Uvajanje e-poslovanja na sodišče kot storitev e-uprave

justice contains following projects: Certificate of no criminal record, Legal Information Systems, Registers and Information Systems for Monitoring Judicial Procedures. Some of the projects such as Legal Information System and Legal Practice of the Supreme Court of the Republic of Slovenia, Public Accessibility to Land Registers and Legal Registers are finished or just at the end of the developmental stage. Some of them like Monitoring Civil Procedures or Monitoring Execution Procedures, however, have not started at all.

\section{Possibilities of adopting Information Technology at court}

Susskind suggests more opportunities for connecting lawyers and information technology. Lawyers mostly use information technology for purposes of automating the old techniques of existing practice or finding innovations and new ways of carrying out tasks. Lawyers use information technology for: electronic communication, creating and managing documents, support at legal proceedings, self-knowledge support systems, searching for information and for case management systems.

Such systems or services are: specialized legal portals, organizational intranet, trial support information systems, networks, automated document systems, legal diagnostic systems, speech recognition systems, videoconferencing, etc.

\section{Survey}

In December 2003 we performed an e-mail survey among Slovenian lawyers. Questionnaires were sent to 800 e-mail addresses. Most participants were judges $(36 \%)$, followed by lawyers $(35.4 \%)$, jurists $(13.7 \%)$, and other professions $(14.9 \%)$.

Almost all survey participants (98.8\%) owned a PC connected to the Internet at work. More than half of participants (57.7\%) spent less than 1 hour on the Internet, and $27 \%$ spent more than one but less than two hours on the Internet. Almost $90 \%$ of participants did use World Wide Web. Among possible reasons for using the web, participants picked the following answers: search for court decisions $(93.3 \%)$, search for codes of law (91\%), and search for legal literature (83.6\%), surprisingly, e-banking was used by $16.4 \%$ of participants.

Through opinions we measured whether it was possible to introduce e-business at court in Slovenia; especially what were the participants' opinions on what should be introduced or achieved, and what were their expectations on introducing new services. 
Slightly less than one half of participants believed that it is possible to file documents at court electronically in two years, whilst others did not believe or know it would happen.

Expectations on electronic filing at court are high among the participants. $47 \%$ of them strongly agree and $41 \%$ agree with the opinion that courts should enable electronic filing for interested parties.

Would electronic filing enable quicker and cheaper trial at courts? $47 \%$ of participants in overall agreed or strongly agreed that electronic filing would quicken the trial. Moreover, $60 \%$ of participants agreed or strongly agreed that electronic filing would lower the costs of the trial. Similar results were shown with the opinion that courts should send their writings of trials to interested parties electronically.

Some of the participants tested a prototype solution, which enables electronic communication and collaboration among parties and court. The benefit of the prototype solution is that for instance lawyers can file a document to the court at anyplace anytime and also receive a document in the same manner. The participants were asked to complete a part of a trial at court electronically in triples of one judge and two lawyers.

After the test they filled out a questionnaire about fulfillment of their expectations on prototype solution. In overall they were satisfied with the prototype.

\section{Conclusions}

If we gather the results of the survey, we can conclude that Slovenian lawyers are quite willing for adopting e-business at their every-day work. They are well equipped and they actively use the benefits of information technology and e-business. Regardless of the results of perception of e-business, lawyers would like to use new services because their expectations are high and they see advantages in e-business, especially with e-filing of documents to the court and receiving legal writings from court electronically. 